\title{
The Ventral Premammillary Nucleus Links Fasting-Induced Changes in Leptin Levels and Coordinated Luteinizing Hormone Secretion
}

\author{
Jose Donato Jr, ${ }^{1,2}$ Renata J. Silva, ${ }^{1}$ Luciane V. Sita, ${ }^{1}$ Syann Lee, ${ }^{2}$ Charlotte Lee, ${ }^{2}$ Sílvia Lacchini, ${ }^{1}$ Jackson C. Bittencourt, ${ }^{1}$ \\ Celso R. Franci, ${ }^{3}$ Newton S. Canteras, ${ }^{1}$ and Carol F. Elias ${ }^{1,2}$ \\ ${ }^{1}$ Department of Anatomy, Institute of Biomedical Sciences, University of São Paulo, São Paulo, São Paulo 05508-900, Brazil, ${ }^{2}$ Division of Hypothalamic \\ Research, Department of Internal Medicine, University of Texas Southwestern Medical Center, Dallas, Texas 75390, and ${ }^{3}$ Department of Physiology, School \\ of Medicine of Ribeirão Preto, University of São Paulo, Ribeirão Preto, São Paulo 14049-900, Brazil
}

\begin{abstract}
Physiological conditions of low leptin levels like those observed during negative energy balance are usually characterized by the suppression of luteinizing hormone (LH) secretion and fertility. Leptin administration restores LH levels and reproductive function. Leptin action on LH secretion is thought to be mediated by the brain. However, the neuronal population that mediates this effect is still undefined. The hypothalamic ventral premammillary nucleus (PMV) neurons express a dense concentration of leptin receptors and project to brain areas related to reproductive control. Therefore, we hypothesized that the PMV is well located to mediate leptin action on LH secretion. To test our hypothesis, we performed bilateral excitotoxic lesions of the PMV in adult female rats. PMV-lesioned animals displayed a clear disruption of the estrous cycle, remaining in anestrus for 15-20 d. After apparent recovery of cyclicity, animals perfused in the afternoon of proestrus showed decreased Fos immunoreactivity in the anteroventral periventricular nucleus and in gonadotropin releasing hormone neurons. PMV-lesioned animals also displayed decreased estrogen and LH secretion on proestrus. Lesions caused no changes in mean food intake and body weight up to 7 weeks after surgery. We further tested the ability of leptin to induce LH secretion in PMV-lesioned fasted animals. We found that complete lesions of the PMV precluded leptin stimulation of LH secretion on fasting. Our findings demonstrate that the PMV is a key site linking changing levels of leptin and coordinated control of reproduction.
\end{abstract}

\section{Introduction}

Physiological conditions of low leptin levels like those observed during negative energy balance are usually characterized by the suppression of luteinizing hormone (LH) secretion and fertility (Foster et al., 1989; Manning and Bronson, 1989; Parfitt et al., 1991; Maffei et al., 1995; Weigle et al., 1997). Leptin administration during negative energy balance restores LH levels and reproductive function (Ahima et al., 1996; Nagatani et al., 1998; Gonzalez et al., 1999; Watanobe et al., 1999; Chan et al., 2003; Welt et al., 2004). Leptin action on reproduction is also supported by the reproductive deficits and infertility displayed by leptin-deficient $(o b / o b)$ or resistant $(d b / d b)$ mice (Zhang et al., 1994; Tartaglia et al., 1995). This phenotype is recapitulated in

Received Jan. 26, 2009; revised March 21, 2009; accepted March 22, 2009.

Financial support was received from Regent's Scholar Research Award [University of Texas Southwestern Medical Center (UTSW)], Conselho Nacional de Desenvolvimento Científico e Tecnológico, and Fundação de Amparo à Pesquisa do Estado de São Paulo (Grants 04/13850-30, 04/13849-5, 04/09638-9, 05/58997-4, and 05/59286-4). Leptin assays were performed by the Metabolic Core at UTSW, Dallas, TX (funded by National Institutes of Health Grant 1PL1DK081182-01). We thank Drs. Robert Steiner (University of Washington, Seattle, WA) and Rexford Ahima (University of Pennsylvania, Philadelphia, PA) for supplying the NPY and the GnRH CDNAs. We thank Amanda Oliveira, Renata Frazão, Marta Righetti, Laura Brule, and Rogério Azevedo for technical assistance.

Correspondence should be addressed to Dr. Carol F. Elias, Department of Internal Medicine, University of Texas Southwestern Medical Center, 5323 Harry Hines Boulevard, Y6-220 Dallas, TX 75390. E-mail: carol.elias@utsouthwestern.edu.

DOI:10.1523/JNEUROSCI.0405-09.2009

Copyright $\odot 2009$ Society for Neuroscience $\quad$ 0270-6474/09/295240-11\$15.00/0 humans with monogenic forms of leptin-signaling deficiency (Montague et al., 1997; Clément et al., 1998). Leptin administration to leptin-deficient subjects and to $o b / o b$ mice induces gonadotropin secretion and restores fertility (Barash et al., 1996; Chehab et al., 1996; Farooqi et al., 1999, 2002).

The leptin receptors (LepRs) are expressed in different organs and tissues (Zamorano et al., 1997). Recent studies demonstrated that brain-specific expression of LepRs rescues many aspects of the leptin receptor-deficient phenotype (de Luca et al., 2005). However, the specific sites mediating leptin's effect on reproduction remain uncertain. Considerable attention has been given to the arcuate nucleus (Arc), where LepRs are expressed in NPY/ AgRP (agouti-related protein), POMC (proopiomelanocortin), and Kisspeptin neurons (Elmquist et al., 2005; Schwartz and Porte, 2005; Smith et al., 2006a). Available evidence suggests that neither melanocortin nor NPY neurons are the key link between leptin and the reproductive axis (Yeo et al., 1998; Hohmann et al., 2000). For example, mice with deletion of leptin signaling in melanocortin neurons are fertile and produce normal litter sizes (Balthasar et al., 2004; van de Wall et al., 2008). Similarly, NPY action in modulating reproductive function is well accepted, but its role as a mediator of leptin action on reproduction is unclear (Hill et al., 2008). For example, mice with deletion of the NPY gene are fertile, and $o b / o b$ mice deficient in NPY show only modest improvement of the reproductive function (Erickson et al., 1996). Compared with wild type, Kisspeptin gene expression 
(Kiss1) is low in $o b / o b$ mice and leptin administration partially restores Kiss1 levels (Smith et al., 2006a). However, selective reexpression of LepR in the Arc of LepR null mice did not rescue their reproductive function (Coppari et al., 2005). Collectively, these findings indicate that other brain sites mediate leptin action on reproduction.

The ventral premammillary nucleus (PMV) contains a dense concentration of leptin-responsive neurons and projects to areas related to reproductive control (Canteras et al., 1992; Elias et al., 2000; Rondini et al., 2004). The PMV is also part of the brain circuitry involved in olfactory modulation of the reproductive behavior (Winans and Powers, 1977; Beltramino and Taleisnik, 1985). For example, estrogen-primed ovariectomized female rats exposed to male odors exhibited an increase in LH secretion (Beltramino and Taleisnik, 1983). This response was blocked in animals with bilateral lesions of the PMV (Beltramino and Taleisnik, 1985). However, the physiological relevance of the PMV for female reproductive function is unknown. In particular, the PMV action linking changing levels of leptin and LH secretion has not been tested. In the present study, we assessed whether the PMV is required for coordinated reproductive control and for leptin stimulation of LH secretion during fasting.

\section{Materials and Methods}

Animals. Adult female Sprague Dawley rats (54 $\pm 1 \mathrm{~d}$ old) were maintained on a $12 \mathrm{~h}$ light/dark cycle and temperature-controlled environment, with ad libitum access to water and food. All experiments were performed in accordance with the guidelines of the National Institute of Health Guide for the Care and Use of Laboratory Animals (1996) and Institutional Committee for Research and Animal Care of the University of São Paulo.

Stereotaxic surgical procedure. The stereotaxic surgery was performed under Equitesin anesthesia (i.p., $3 \mathrm{mg} / 100 \mathrm{~g}$ sodium thiopental, $12.7 \mathrm{mg} / 100 \mathrm{~g}$ chloral hydrate). NMDA $(0.15 \mathrm{M}$, Sigma $)$ or saline was injected iontophoretically from a glass micropipette into the PMV bilaterally (coordinates: anteroposterior (from bregma) $=-3.9$; mediolateral (from midline) $= \pm 0.7$; dorsoventral (from dura-mater) $=-8.5$ ), by applying $-8 \mu \mathrm{A}$ pulsed current at $7 \mathrm{~s}$ intervals, for 15 $\mathrm{min}$. The NMDA is effective in inducing excitotoxic neuronal lesion without affecting fibers of passage (Sisk et al., 1988). Animals were housed individually after surgery.

Estrous cycle, body weight, and food intake. The estrous cycle was assessed daily by analysis of the vaginal cytology throughout the experiment. Only animals presenting two consecutive 4 to $5 \mathrm{~d}$ estrous cycles before surgery were used. We considered a day as proestrus when a high percentage of nucleated cells and a minimum amount of leukocytes were identified, preceded by $2 \mathrm{~d}$ of diestrus (prevalence of leukocytes). Body weight was assessed weekly throughout the experiment. Food intake was assessed only after full recovery from the surgical procedure (after 3 weeks). All animals were cycling during food intake assessment. We measured food intake daily for 20 consecutive days ( $4-5$ cycles) at the same time of the day (1:00 P.M.). The NMDA- and the saline-injected animals were divided in two groups: one perfused on proestrus and the other perfused on diestrus 1 . All animals were perfused $1 \mathrm{~h}$ ( $\pm 10 \mathrm{~min}$ maximum) before lights off.

Responsiveness to central leptin administration. A group of PMVlesioned and nonlesioned saline injected females were ovariectomized and, after 3 weeks, were implanted with intracerebroventricular cannulas and intravenous lines. The cannulas were positioned into the lateral ventricles (coordinates: anteroposterior (from bregma) $=-0.4$; mediolateral $($ from midline $)=-1.4$; dorsoventral (from dura-mater $)=-3.8$ ). The intravenous lines were inserted into the right external jugular vein and advanced to the right atrium to permit repeated blood collections. The free end of the catheter was exteriorized between the scapulae and plugged with a sterile wire stylet. Forty-eight hours before the test, animals were fasted and received a single subcutaneous administration of estradiol-benzoate ( $300 \mu \mathrm{g} / \mathrm{ml}$, Sigma) in $0.2 \mathrm{ml}$ of sesame oil. Experi- ments were performed during the morning (8:00-11:00 A.M.) and consisted of an initial collection of blood sample (considered our baseline), followed by intracerebroventricular administration of $10 \mu \mathrm{l}$ of saline or leptin $(1 \mu \mathrm{g} / \mu \mathrm{l}$ diluted in saline, Sigma) for $1 \mathrm{~min}$. Subsequently, blood samples were collected in $10 \mathrm{~min}$ intervals during $1 \mathrm{~h}$. After removal of each blood sample $(\sim 0.3 \mathrm{ml})$, an equal volume of heparinized $(10 \mathrm{UI} / \mathrm{ml})$ saline was injected to restore the blood volume. Animals were deeply anesthetized and perfused. Immediately before perfusion another blood sample was collected (70 min after leptin or saline administration). To establish complete or partial lesions, we used thionin staining and immunohistochemistry to detect phosphorylation of the signal transducer and activator of transcription type 3 (pSTAT3) as a marker for leptin signaling (Bates et al., 2003). Our control groups consisted of nonlesioned animals treated with saline or leptin.

Perfusion and histology. Animals were deeply anesthetized with ketamine ( $5 \mathrm{mg} / 100 \mathrm{~g})$, xylazine $(1 \mathrm{mg} / 100 \mathrm{~g})$, and acepromazine $(0.2 \mathrm{mg} /$ $100 \mathrm{~g})$. Animals were perfused with $4 \%$ paraformaldehyde in boratebuffer $\left(\mathrm{pH} 9.5\right.$ at $\left.4^{\circ} \mathrm{C}\right)$. Brains were cryoprotected overnight at $4^{\circ} \mathrm{C}$ in

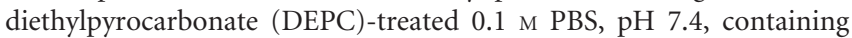
$20 \%$ sucrose. The brains were cut ( $30 \mu \mathrm{m}$ sections) in the frontal plane in a freezing microtome. Five series were collected and stored at $-20^{\circ} \mathrm{C}$. The extent of lesions and the preservation of hypothalamic nuclei were assessed by thionin staining. In addition, in the leptin responsiveness test, the extent of the lesions was also determined by the detection of pSTAT3 immunoreactivity. Ovaries were processed for standard paraffin embedded sectioning and hematoxylin-eosin staining.

Immunohistochemistry. Hypothalamic sections containing the preoptic area and the vascular organ of laminae terminalis (OVLT) were pretreated with hydrogen peroxide, blocked in 3\% normal donkey serum, and incubated overnight at room temperature in anti-Fos polyclonal primary antisera raised in rabbit (Ab5, 1:70,000, Oncogene). Sections were incubated for $1 \mathrm{~h}$ in biotin-conjugated IgG donkey anti-rabbit (1: 1000, Jackson Laboratories) and for $1 \mathrm{~h}$ in avidin-biotin complex (1:500, Vector Labs). The peroxidase reaction was performed using 0.05\% DAB and $0.025 \%$ nickel sulfate as chromogens, and $0.03 \%$ hydrogen peroxide. We then incubated the tissue overnight at room temperature in rabbit primary anti-gonadotropin releasing hormone $(\mathrm{GnRH})$ antisera (1:5000, ImmunoStar). Sections were processed as described except that only DAB was used as chromogen.

For pSTAT3 detection, immunoperoxidase reaction was performed as described except that sections were additionally pretreated in $0.3 \%$ glycine and $0.03 \%$ lauryl sulfate before primary incubation. Sections were incubated in anti-pSTAT3 raised in rabbit (1:4000, Cell Signaling Technology) for $48 \mathrm{~h}$ at $4^{\circ} \mathrm{C}$. Peroxidase reactions were performed using DAB and nickel as chromogens.

In situ hybridization histochemistry. Before hybridization, brain sections were mounted onto SuperFrost plus slides (Fisher Scientific), pretreated with proteinase $\mathrm{K}$ (Roche) and with triethanolamine plus acetic anhydride. The riboprobes (GnRH, NPY, and Kiss1) were generated by in vitro transcription with ${ }^{35} \mathrm{~S}$-UTP. The ${ }^{35} \mathrm{~S}$-labeled probes were diluted $\left(10^{6} \mathrm{dpm} / \mathrm{ml}\right)$ in hybridization solution. The solution consisted of $50 \%$ formamide, $10 \mathrm{~mm}$ Tris- $\mathrm{HCl}$ (Invitrogen-BRL), 0.01\% sheared salmon sperm DNA, $0.01 \%$ yeast tRNA, $0.05 \%$ total yeast RNA (Sigma), $10 \mathrm{~mm}$ dithiothreitol, $10 \%$ dextran sulfate, $0.3 \mathrm{M} \mathrm{NaCl}, 1 \mathrm{~mm}$ EDTA, pH 8.0, and $1 \times$ Denhardt's solution (Sigma). The hybridization solution $(120 \mu \mathrm{l})$ and a coverslip were applied to each slide and sections were incubated at $56^{\circ} \mathrm{C}$ for $12-16 \mathrm{~h}$. On the following day, sections were incubated in $0.002 \%$ RNAase A solution and submitted to stringency washes in decreasing concentrations of sodium chloride/sodium citrate buffer (SSC). Sections were then dehydrated and enclosed in $\mathrm{x}$-ray film cassettes with BMR-2 film (Kodak) for 1-2 d. Slides were dipped in NTB2 photographic emulsion (Kodak), dried, and stored at $4^{\circ} \mathrm{C}$ for $7-10 \mathrm{~d}$. Slides were developed with a D-19 developer (Kodak), dehydrated, cleared in xylene, and coverslipped with DPX.

The GnRH cDNA was kindly provided by Dr. Rexford Ahima (University of Pennsylvania, Philadelphia, PA), and its specificity was previously described (Bond et al., 1989). The NPY cDNA was kindly provided by Dr. Robert Steiner (University of Washington, Seattle, WA) and the NPY ${ }^{35}$ S-labeled riboprobes were generated as described previously 



Figure 1. Bilateral excitotoxic lesions of the PMV cause transitory anestrus. $A, B$, Brightfield photomicrographs of brain sections stained with thionin showing the PMV of a control $(\boldsymbol{A})$ and of a PMV-lesioned animals $(\boldsymbol{B})$. Note that the PMV neurons are intact in control and absent in PMV-lesioned animals. Also observe that adjacent nuclei are preserved indicating the specificity of the lesion. C, Schemes showing the estrous cycle of representative cases of control and PMV-lesioned animals. Estrous cycle was assessed by the analysis of the vaginal cytology. Each line represents one animal and arrows indicate the day in which stereotaxic surgery was performed. We observed that all PMV-lesioned animals showed a $2-3$ weeks of anestrus $(n=12)$, whereas no control animal ( $n=11$ ) showed changes in cyclicity. All schemes represent the entire experimental period and, therefore, end on the perfusion day. Animals represented in this figure were perfused on proestrus. PMV-lesioned animals displayed a minimum of five complete cycles before the perfusion. $3 v$, Third ventricle; C, cornified cells (estrus); $f$, fornix; $N$, nucleated epithelial cells (proestrus); L, leukocytes (diestrus). Scale bar, $400 \mu \mathrm{m}$.

(Chan et al., 1996). The Kiss1 probe was derived from PCR fragments amplified with iTaq DNA polymerase (Bio-Rad) from cDNA generated with the SuperScript III First-Strand Synthesis System for Rt-PCR (Invitrogen) from total mouse hypothalamic RNA. The PCR products were cloned with the TOPO TA Cloning Kit for Sequencing (Invitrogen). The Kiss1 probe includes positions 77-480 of GenBank accession number NM_178260. Hybridization with sense probes and after RNase treatment was performed as a control.

Hormone assays. Commercial radioimmunoassay kits were used to measure the levels of estradiol (BioChem ImmunoSystems), progesterone (BioChem ImmunoSystems), and testosterone (DSL). The lower detection limit and the intra-assay coefficient of variation were respectively $7.5 \mathrm{pg} / \mathrm{ml}$ and $2.5 \%$ for estradiol, $4.1 \mathrm{ng} / \mathrm{ml}$ and $3.7 \%$ for progesterone, and $0.08 \mathrm{ng} / \mathrm{ml}$ and $8.5 \%$ for testosterone. LH and FSH were determined by radioimmunoassay using kits provided by National Hormone and Peptide Program as described previously (Anselmo-Franci et al., 1997). The reference preparations were $\mathrm{LH}-\mathrm{RP}_{3}$ and $\mathrm{FSH}-\mathrm{RP}_{2}$. The lower detection limits were $0.05 \mathrm{ng} / \mathrm{ml}$ and 0.2 $\mathrm{ng} / \mathrm{ml}$, the intra-assay coefficients of variation were $4 \%$ and $3 \%$, for $\mathrm{LH}$ and FSH, respectively. Serum leptin was analyzed using a commercial ELISA kit (Crystal Chem). The changes in LH levels after leptin or saline administration were assessed as $\mathrm{LH}$ area under the curve across the period of blood collection ( 7 samples in $70 \mathrm{~min}$ ), the area under the curve of the highest $\mathrm{LH}$ pulse, the maximum LH concentration, and the mean LH concentration. Data are expressed as mean \pm SEM.

Quantification. Quantifications were performed by an observer unaware of the experimental groups. Fos-ir located inside the boundaries of the anteroventral periventricular nucleus (AVPV) were quantified in both sides under $10 \times$ or $20 \times$ magnification. Colocalization of GnRH-ir and Fos-ir was determined in 3 rostro-to-caudal levels of the preoptic area containing the OVLT (150 $\mu \mathrm{m}$ intervals). These levels were defined according to previous studies which demonstrated that the majority of GnRH neurons expressing Fos-ir in the afternoon of proestrus are located in the adjacencies of the OVLT (Lee et al., 1990; Wang et al., 1995). Number of follicles and corpora lutea was counted in one representative section of the ovaries under $10 \times$ or $20 \times$ magnification.

The hybridization signal was estimated by the analysis of the integrated optical density (IOD) using the ImageJ software (http://rsb.info.nih.gov/ij). Darkfield photomicrographs were acquired using the same illumination and exposure time for every section. No image editing was processed before quantifications. The IOD values for NPY mRNA were calculated as the total IOD of a constant area $\left(0.3 \mathrm{~mm}^{2}\right)$ subtracting the background. The area of interest was positioned using as reference the wall of the third ventricle and the base of the brain. The background was obtained from adjacent nuclei that do not express NPY. For the quantification of GnRH mRNA expression we assessed the IOD of individual cells. We considered only the cells that had IOD values at least 3 times higher than that of background located in the adjacencies of the OVLT. Only the OVLT level was quantified because, as mentioned, this is the level where a higher proportion of GnRH neurons coexpressing Fos-ir in the afternoon of proestrus is observed (Lee et al., 1990; Wang et al., 1995; Rondini et al., 2004). For the quantification of Kiss 1 mRNA we assessed the total IOD of a constant area, the IOD of individual cells and the number of cells located in the AVPV and in the Arc. The procedure for the quantification of the hybridization signal on Kiss1 neurons were the same as described for GnRH. The procedure for the quantification of total IOD values for Kiss 1 was the same as described for NPY. For the AVPV, the area of interest $\left(0.14 \mathrm{~mm}^{2}\right)$ was also positioned considering the wall of the third ventricle and the lateral border of the nucleus observed in brightfield.

Data analysis and production of photomicrographs. Brain and ovary sections were analyzed in a Leica DMR microscope. The photomicrographs were captured with a SPOT RT digital camera (Diagnostic Instruments), adapted to a Leica DMR microscope (Leica) and a Dell Dimension 4400 computer. Images were digitalized using Image Pro Plus. Adobe Photoshop 7.0 image-editing software was used to integrate photomicrographs into plates. Only sharpness, contrast and brightness were adjusted.

Statistical analysis. Data are expressed as mean \pm SEM. Comparison between the two groups was performed using the unpaired two-tailed Student's $t$ test. One-way ANOVA followed by the pairwise Tukey test were used to compare three or more groups simultaneously. Statistical analysis was performed using GraphPad Prism software, and an $\alpha$ value of 0.05 was considered in all analyses.

\section{Results}

Bilateral lesions of the PMV cause a transient disruption of the estrous cycle

In the first set of experiments, we determined whether the PMV is required for normal female reproductive physiology. For this purpose, we made bilateral excitotoxic lesions of the PMV in 
adult rats. In this group, the extent of the lesion was determined by thionin staining. We obtained 12 animals with specific, complete, and bilateral lesions of the PMV (classified as PMVlesioned animals), 4 animals with partial lesions of the PMV (used as control for nonspecific responses to NMDA toxicity), and 11 animals injected with saline (Fig. $1 A, B$ ).

After surgery, PMV-lesioned animals displayed a clear disruption of the estrous cycle, remaining in anestrus for 15-20 d (Fig. 1C). During anestrus, animals exhibited vaginal cytology suggestive of diestrus. After this period, animals displayed cyclicity, although the vaginal cytology continued to exhibit an atypical mixed cell profile. We considered the vaginal cytology atypical because the PMV-lesioned rats displayed an increased number of cornified cells during proestrus and increased number of epithelial and cornified cells during diestrus 1 and 2 in the vaginal lavage compared with cycles observed before surgery and to those observed in nonlesioned control animals. All control females, including the saline injected animals and those with partial lesions, showed regular unaltered estrous cyclicity and vaginal cytology after surgery (Fig. 1C). Animals were perfused $\sim 7$ weeks after the surgery. Before perfusion, the PMV-lesioned animals had displayed $7.5 \pm 0.5$ complete estrous cycles and nonlesioned animals had displayed $11.0 \pm$ 0.4 cycles.

\section{Bilateral lesions of the PMV disrupt the activation of key hypothalamic sites on proestrus}

We observed that control animals perfused in the afternoon of proestrus (1 h before lights off) showed the expected Fos expression in GnRH neurons (Lee et al., 1990; Le et al., 1999). However, in the PMV-lesioned animals, the number of GnRH neurons coexpressing Fos was significantly reduced (Fig. $2 A, B)$. Previous studies have suggested that GnRH neurons expressing Fos on proestrus are more transcriptionally active as they show increased GnRH mRNA expression (Wang et al., 1995). These neurons are concentrated in the vicinity of the OVLT and comprise the subset of GnRH cells that projects to the median eminence and controls LH secretion (Jennes and Stumpf, 1986; Silverman et al., 1986). Thus, we assessed the expression of the GnRH mRNA in neurons distributed around the OVLT, where we found a higher number of GnRH neurons expressing Fos. The number of GnRH neurons was not different $(p=0.843)$ between control $(45.2 \pm 2.5)$ and PMVlesioned $(46.0 \pm 2.7)$ animals. However, GnRH mRNA expression in individual cells was decreased in PMV-lesioned animals compared with control animals (Fig. 2A,C).

The AVPV is a key site of estrogen positive feedback action on LH secretion (Wiegand and Terasawa, 1982; Wintermantel et al., 2006; Herbison, 2008). During the preovulatory LH surge, AVPV neurons show Fos immunoreactivity concomitant with Fos expression in GnRH neurons (Le et al., 1999). As expected, control animals displayed high Fos expression in the AVPV. However, PMV-lesioned animals showed lower Fos immunoreactivity compared with control animals (Fig. $3 A, B$ ).

Some of the AVPV neurons that are immunoreactive for Fos during proestrus coexpress Kiss1 (Smith et al., 2006b). Thus, we assessed Kiss1 expression in the AVPV of animals perfused in the afternoon of proestrus (Fig. 3C). We found no changes on total number of Kiss1 neurons (control: $53.5 \pm 11.6 \mathrm{IOD} /$ neurons; PMV-lesioned: $59.6 \pm 6.7$ IOD/neurons; $p=0.6359$ ), on Kiss 1 expression in individual neurons (control: $1.86 \pm 0.29$ neurons; PMV-lesioned: $1.96 \pm 0.19$ neurons; $p=0.7609$ ), and on total
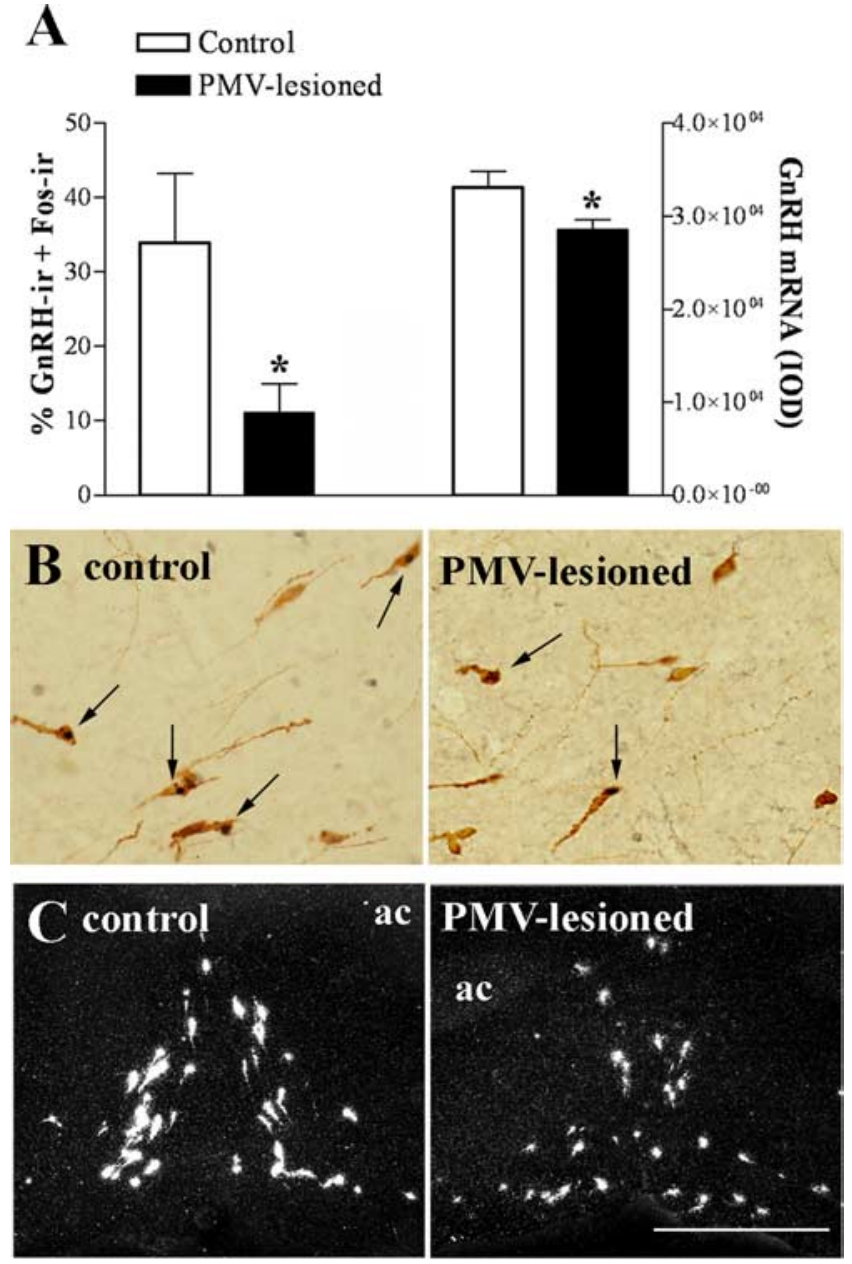

Figure 2. Bilateral lesions of the PMV disrupt the activation of GnRH neurons in the afternoon of proestrus. The animals were perfused on proestrus $1 \mathrm{~h}$ before lights off, $\sim 7$ weeks after the stereotaxic surgery. $A$, Bar graphs showing the percentage of $\mathrm{GnRH}$ neurons expressing Fos in control $(n=6)$ and PMV-lesioned animals $(n=8)$, as well as the quantification of hybridization signal (IOD/cell) of GnRH-positive cells in control $(n=5)$ and PMV-lesioned animals $(n=8)$. Lesions of the PMV caused a reduction in the number of GnRH neurons expressing Fos immunoreactivity ( $p=0.0282$ ), and in the GnRH mRNA expression ( $p=0.0341$ ), compared with control group. $\boldsymbol{B}$, Brightfield photomicrographs showing the coexpression of Fos immunoreactivity (dark nucleus) in GnRH cells (brown cytoplasm) of control and PMV-lesioned animals. Arrows indicate dual labeled neurons. C, Darkfield photomicrographs showing GnRH mRNA (silver grains) adjacent to the OVLT of control and PMV-lesioned animals. Scale bar: (in C) B, 400 $\mu \mathrm{m} ; \boldsymbol{C}, 200 \mu \mathrm{m} . \mathrm{ac}$, Anterior commissure. *Statistically different compared with control animals.

Kiss 1 expression (data not shown) in the AVPV of PMV-lesioned compared with control animals.

\section{Bilateral lesion of the PMV blunts estradiol and gonadotropins levels on proestrus}

We further assessed the hormonal profile of animals in the afternoon of proestrus ( $1 \mathrm{~h}$ before lights off), when we expect to see the preovulatory LH surge (Eskay et al., 1977). Another group was perfused in the afternoon of diestrus 1 ( $1 \mathrm{~h}$ before lights off), to assess basal conditions.

During diestrus 1 , no significant changes were observed between control and PMV-lesioned animals (Fig. 4A-C). However, on proestrus, PMV-lesioned animals displayed lower levels of estradiol and testosterone compared with the control group (Fig. $4 A, B)$. No significant differences in progesterone were observed between groups (Fig. 4C). The LH and FSH levels were assessed 

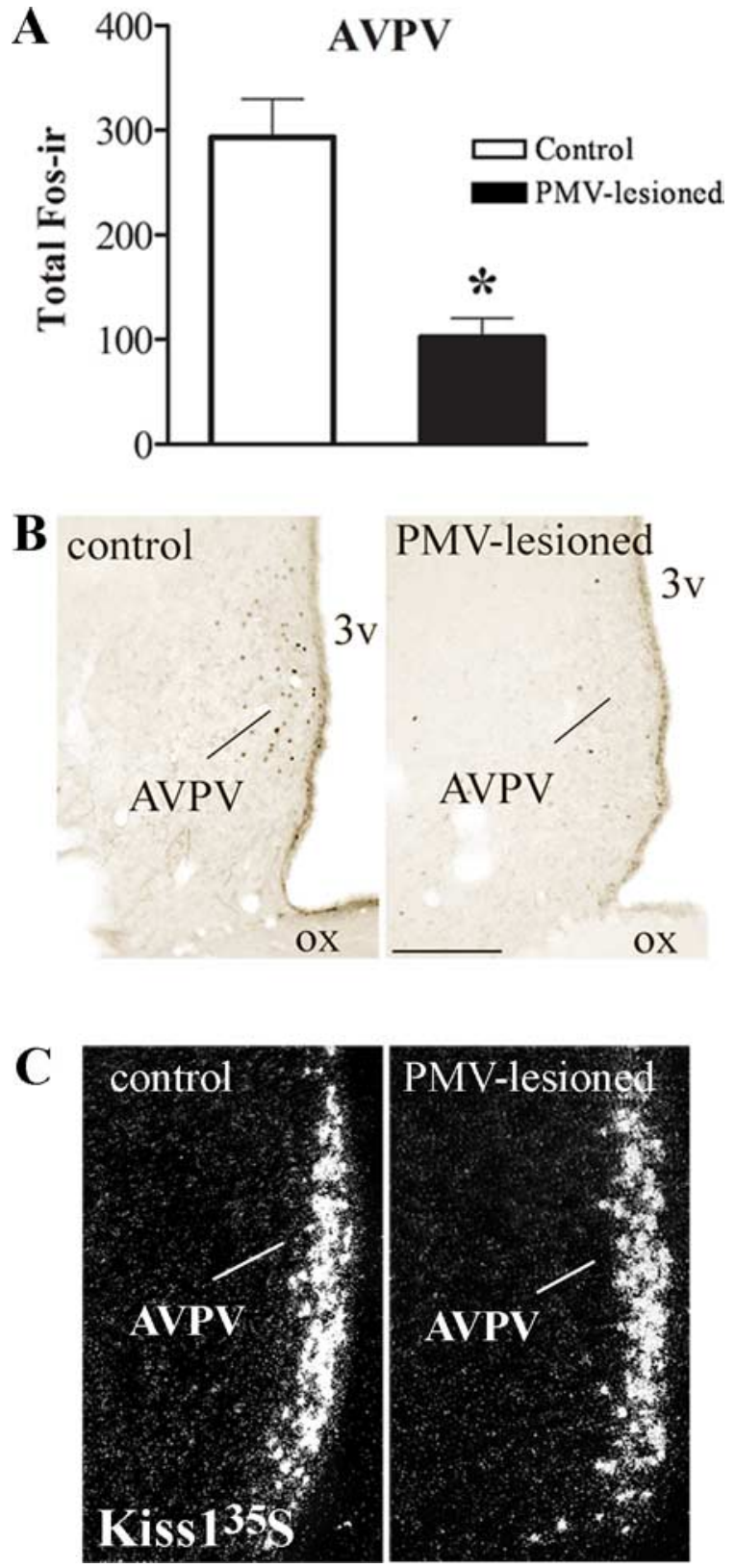

Figure 3. Bilateral lesions of the PMV disrupt the activation of AVPV neurons in the afternoon of proestrus. The animals were perfused on proestrus $1 \mathrm{~h}$ before lights off, $\sim 7$ weeks after the stereotaxic surgery. $A$, Bar graphs showing the number of cells expressing Fos-ir in the AVPV of control and PMV-lesioned animals ( $p=0.0003)$. B Brightfield photomicrograph showing the distribution of Fos-ir in the AVPV of control and PMV-lesioned animals. C, Darkfield photomicrographs showing Kiss1 mRNA (silver grains) in the AVPV of control and PMV-lesioned animals. Scale bar: (in $\boldsymbol{B}) \boldsymbol{B}, 200 \mu \mathrm{m} ; \boldsymbol{C}, 180 \mu \mathrm{m}$. 3v, Third ventricle; 0x, optic chiasm. * Statistically different compared with control animals.

individually because of their inherent pulsatile secretion. We evaluated the number of animals that presented LH levels indicative of LH surge. We found that $83 \%$ of control animals displayed LH surge $(>8 \mathrm{ng} / \mathrm{ml}$; mean LH levels on diestrus 1 as reference: $2.6 \pm 0.6 \mathrm{ng} / \mathrm{ml}$, range: $0.8-5.5 \mathrm{ng} / \mathrm{ml}$ ). Remarkably, only $25 \%$ of PMV-lesioned rats displayed comparable levels. The secretion of FSH during proestrus was also blunted in PMVlesioned animals. We observed that $50 \%$ of the control animals displayed increased FSH levels on the afternoon of proestrus $(>4.5 \mathrm{ng} / \mathrm{ml}$; mean FSH levels on diestrus 1: $1.9 \pm 0.2 \mathrm{ng} / \mathrm{ml}$,
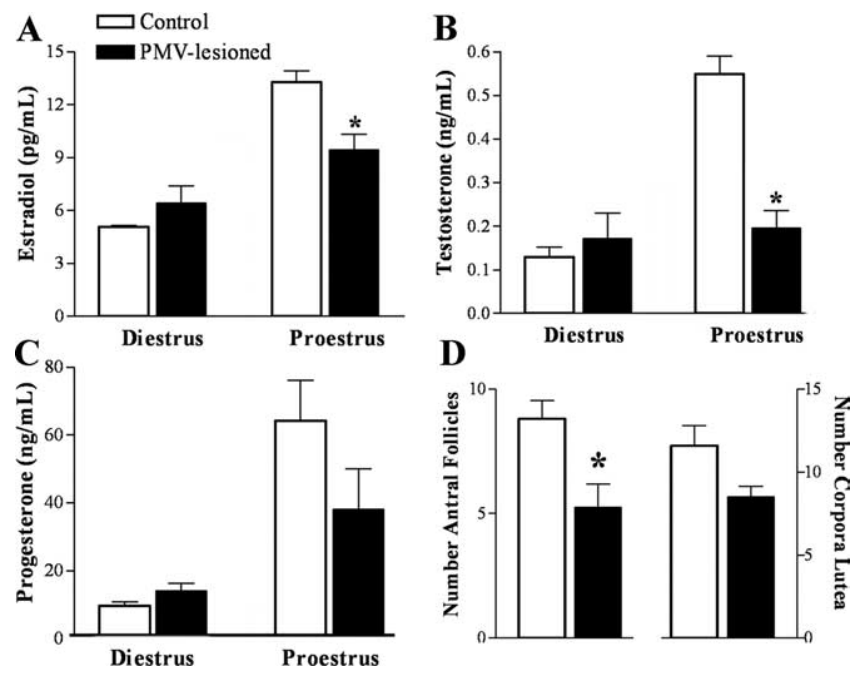

Figure 4. Bilateral lesion of the PMV blunt sexual steroids levels in the afternoon of proestrus. Blood samples were collected immediately before the perfusion. Perfusion was performed in animals on diestrus 1 or proestrus, $1 \mathrm{~h}$ before lights off. $\boldsymbol{A}-\boldsymbol{C}$, Bar graphs showing serum concentrations of estradiol $(A, p=0.0063)$, testosterone $(\boldsymbol{B}, p<0.0001)$, and progesterone $(\boldsymbol{C}, p=0.1562)$, in control and PMV-lesioned animals perfused on diestrus 1 ( $n=4-5$ animals per group) or proestrus ( $n=6-8$ animals per group). $D$, Bar graphs showing the number of antral follicles ( $p=0.0195)$ and corpora lutea $(p=0.0749)$ in control $(n=5)$ and PMV-lesioned ( $n=4)$ animals. *Statistically different compared with control animals.

range: $0.8-3.0 \mathrm{ng} / \mathrm{ml}$ ), but only $12 \%$ of the PMV-lesioned animals also displayed comparable levels.

In addition, we analyzed ovarian histology to assess signs of ovulation. We found that the ovaries of PMV-lesioned animals showed lower number of antral follicles but an equivalent number of corpora lutea compared with control animals (Fig. $4 D)$.

PMV-lesioned animals show no changes in body weight and food intake

Given the dense expression of LepR in the PMV and the well determined role of leptin in energy balance (Elmquist et al., 2005; Schwartz and Porte, 2005), we monitored food intake and body weight of PMV-lesioned and control animals. We found no change in body weight up to 7 weeks after surgery in PMVlesioned and control animals (Fig. 5A). In addition, lesions of the PMV did not change mean daily food intake (control: $21.2 \pm 0.5$ g/d; PMV-lesioned: $21.1 \pm 0.3 \mathrm{~g} / \mathrm{d} ; p=0.8575)$.

Normally cycling females show a reduction in food intake during the transition from proestrus to estrus (Asarian and Geary, 2006). Thus, we compared daily food consumption across the estrous cycle. We found that both groups displayed a reduced food intake during the transition from proestrus to estrus. However, lesions of the PMV caused a significant reduction in the magnitude of this change compared with the control group (Fig. $5 B)$. We then assessed leptin levels to identify any possible alteration or correlation with this change in food intake pattern across estrous cycle. We found no difference in leptin levels between control and PMV-lesioned animals on proestrus or on diestrus 1 (Fig. 5C).

PMV is required for the stimulatory effects of leptin on $\mathrm{LH}$ secretion during fasting

To assess the ability of leptin to induce LH secretion in control and PMV-lesioned animals, we injected intracerebroventricularly leptin $(10 \mu \mathrm{g})$ or saline in $48 \mathrm{~h}$ fasted and ovariectomized 

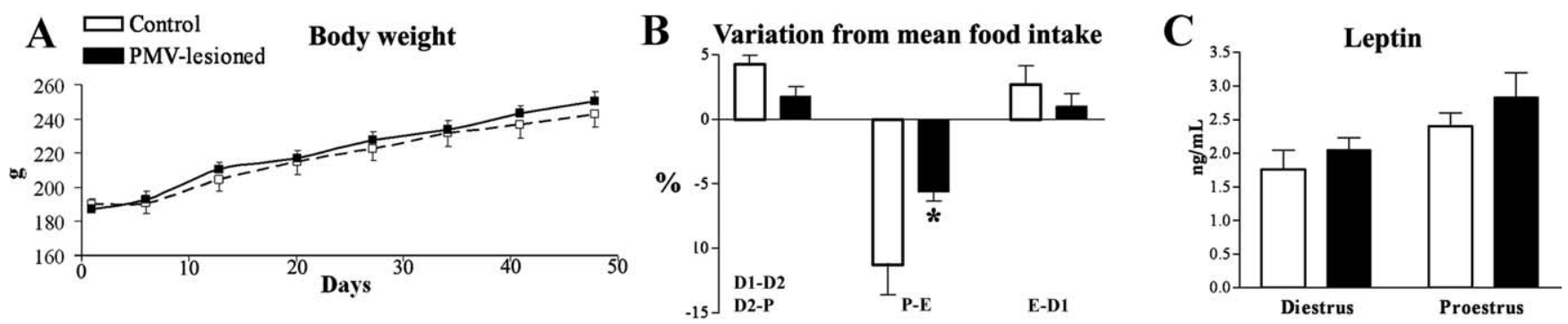

Figure 5. Assessement of metabolic parameters of PMV-lesioned animals. $\boldsymbol{A}$, Graph showing the body weight trajectory of control and PMV-lesioned animals. The body weight was assessed weekly for 7 weeks (day $0=$ estereotaxic surgery). $\boldsymbol{B}$, Bar graphs showing variation in daily food intake across the estrous cycle. Both groups displayed reduced food intake during the transition from proestrus to estrus (P-E). However, PMV lesions caused a significant reduction in the magnitude of this change compared with the control group ( $p=0.018$ ). The magnitude of changes represents the difference between the mean daily food intake determined during the entire period (20 consecutive days) and the mean food intake of each estrous day. Food intake was assessed after full recovery from the surgery (after 3 weeks, for $4-5$ cycles), always at the same time of the day (1:00 P.M.). D1-D2, Transition from diestrus 1 to diestrus 2; D2-P, transition from diestrus 2 to proestrus; E-D1, transition from estrus to diestrus 1; P-E, transition from proestrus to estrus. C, Bar graphs showing serum leptin levels of control and PMV-lesioned animals perfused on diestrus 1 ( $n=4-5$ animals per group, $p=0.4357$ ) and on proestrus $(n=6-8$ animals per group, $p=0.3595)$. ${ }^{*}$ Statistically different compared with control animals.

estrogen-primed rats. We assessed changes on LH levels and/or pulsatility for $70 \mathrm{~min}$ (10 min intervals) in response to intracerebroventricular administration.

Lesions were determined by detection of STAT3 immunoreactivity (a marker for leptin signaling) and confirmed by thionin staining. Control animals treated with leptin showed a dense concentration of pSTAT3 immunoreactive neurons in the PMV (Fig. $6 A$ ). The NMDA injected animals that displayed only decreased leptin-induced pSTAT3 in the PMV were classified as partially lesioned animals. These animals were used as an additional control group. Virtually no pSTAT3 immunoreactivity was observed in the hypothalamus of animals that received saline. We classified PMV-lesioned animals as the cases in which we did not observe any leptin-induced pSTAT3 bilaterally in the PMV (Fig. 6B). All animals treated with leptin displayed pSTAT3 immunoreactivity in other hypothalamic nuclei expressing LepRs, including the Arc, the ventromedial, and the dorsomedial nuclei (data not shown).

As expected, $48 \mathrm{~h}$ fasting caused a marked reduction in the leptin levels, compared with reference values obtained from ad libitum fed female rats (ad libitum: $2.1 \pm 0.2 \mathrm{ng} / \mathrm{ml}$; control+saline: $0.4 \pm 0.1 \mathrm{ng} / \mathrm{ml}$; control+leptin: $0.4 \pm 0.1 \mathrm{ng} /$ $\mathrm{ml}$; PMV-lesioned+leptin: $0.3 \pm 0.1 \mathrm{ng} / \mathrm{ml}$ ).

The baseline levels of LH were not different among groups. We observed that leptin administration induced LH secretion in nonlesioned fasted animals (Fig. 6C,D). However, in animals with complete bilateral lesions of the PMV, leptin treatment failed to induce $\mathrm{LH}$ secretion above that observed for salinetreated fasted animals (Fig. 6C,E). We also found that animals with partial lesion of the PMV showed leptin-induced LH secretion comparable to those observed in control leptin-treated animals (data not shown).

To determine changes in LH levels after intracerebroventricular injection of saline or leptin we assessed the LH area under the curve across the period of blood collection ( 7 samples in $70 \mathrm{~min}$ ), the area under the curve of the highest LH pulse, the maximum LH concentration, and the mean LH concentration in nonlesioned and PMV-lesioned fasted animals. In all parameters analyzed, we observed that nonlesioned leptin-treated animals showed increased values $(p<0.05)$ compared with nonlesioned saline-treated animals (Fig $6 F-I$ ). Nonlesioned leptin-treated animals also displayed increased values in the $\mathrm{LH}$ area under the curve, and in the area under the curve of the highest LH pulse, compared with PMV-lesioned leptin-treated animals (Fig 6F, G). Notably, leptin did not produce any changes on LH secretion in the PMV-lesioned compared with saline treated nonlesioned animals, along the period analyzed (70 $\mathrm{min})$.

We further tested whether the inability of leptin to induce LH secretion in PMV-lesioned fasted animals was caused by disruption of peptidergic systems known to respond to leptin and participate in reproductive control (Gruaz et al., 1993; Ahima et al., 1999; Smith et al., 2006a; Hill et al., 2008). Thus, we assessed changes on Kiss1 expression in the AVPV and Arc, and on NPY mRNA expression in the Arc. We found no differences in number of Kiss1 neurons, in total Kiss 1 mRNA expression and in individual cells Kiss 1 expression in the AVPV or in the Arc in any of the experimental groups (Fig. $7 A-H)$. In addition, we found a lower expression of NPY mRNA in the Arc of fasted animals treated with leptin compared with those treated with saline (Fig. $7 I-L$ ).

\section{Discussion}

Here we show that lesions of the PMV blunt the activation of AVPV and GnRH neurons during the afternoon of proestrus. Lesions also decreased LH and estrogen secretion and disrupted coordinated cyclicity. We found no changes in mean food intake and body weight between PMV-lesioned and nonlesioned animals. Remarkably, in fasted PMV-lesioned animals, central leptin administration failed to induce $\mathrm{LH}$ secretion.

\section{PMV action on coordinated reproductive function}

Based on the connections and the chemical characteristics of PMV neurons, we and others have proposed that the PMV is well located to integrate the brain circuitry that controls reproduction (Simerly et al., 1990; Canteras et al., 1992; Rondini et al., 2004; Cavalcante et al., 2006). PMV neurons express a high concentration of sex steroid receptors and project to reproductive control sites. In particular, PMV neurons densely innervate the AVPV, a key site for the control of female reproductive function (Canteras et al., 1992; Rondini et al., 2004; Hahn and Coen, 2006). The AVPV concentrates estrogen receptors and projects to GnRH neurons (Simerly et al., 1990; Gu and Simerly, 1997; Le et al., 1999; Wintermantel et al., 2006). This pathway is thought to be essential for the positive estrogen action on $\mathrm{GnRH}$ release during the preovulatory $\mathrm{LH}$ surge. In agreement, the decreased activation of the AVPV on proestrus displayed by PMV-lesioned animals was correlated to decreased activation of GnRH neurons and, ultimately, to decreased LH secretion and estradiol levels.

Previous studies have shown that high levels of estrogen in- 
duce an increase in GnRH mRNA (Petersen et al., 1995). Interestingly, PMVlesioned animals displayed decreased GnRH mRNA content in neurons surrounding the OVLT. At this point, it is not possible to determine whether changes in GnRH expression are a consequence of the lack of PMV inputs or the effects of decreased levels of circulating estrogen. However, as the PMV innervates GnRH neurons (Rondini et al., 2004; Boehm et al., 2005) we propose that a direct neural action exists.

Studies in different species and animal models have highlighted the importance of Kisspeptin-Kiss1 receptor system on GnRH physiology (de Roux et al., 2003; Seminara et al., 2003). Most of the AVPV neurons expressing Fos on proestrus coexpress Kiss1 (Smith et al., 2006b). These neurons are also positively regulated by estrogen, as Kiss1 expression decreases in ovariectomized animals and increases after estrogen replacement (Kinoshita et al., 2005; Smith et al., 2006b). In the present study we observed that lesions of the PMV, although they produced low levels of estradiol and decreased Fos immunoreactivity in AVPV neurons, caused no changes in Kiss1 expression. Thus, the decreased levels of estradiol of PMV-lesioned animals may have produced no detectable genomic changes. However, since Fos expression is suggestive of cellular activation (Hoffman and Lyo, 2002), we speculate that the release of neuroactive peptides from AVPV neurons (e.g., Kisspeptins) may be compromised in PMV-lesioned animals. This might explain the blunted activation of GnRH neurons and altered LH secretion observed in our study.

Despite many signs of suppression of the reproductive axis, PMV-lesioned animals showed an apparent recovery of their estrous cycle after several weeks of anestrus. Moreover, the ovaries of lesioned animals contained corpora lutea and, consequently, signs of ovulation. These findings reinforce the argument of the existence of high redundancy and compensatory mechanisms in the neural pathways that control fertility (Bronson, 1998; Herbison et al., 2008). Thus, lesions caused an intermediate stage of suppression of the reproductive axis that did not block episodic ovulation. Interestingly, in conditions of severe food restriction in which fall in leptin levels and changes of the neuroendocrine activity are observed, ovulation still occurs (Terry et al., 2005; Roman et al., 2005). Thus, lesions of the PMV produced a suppression of the reproductive physiology reminiscent to that observed during states of moderate to severe food restriction or of low leptin levels (Terry et al., 2005; Roman et al., 2005).

E
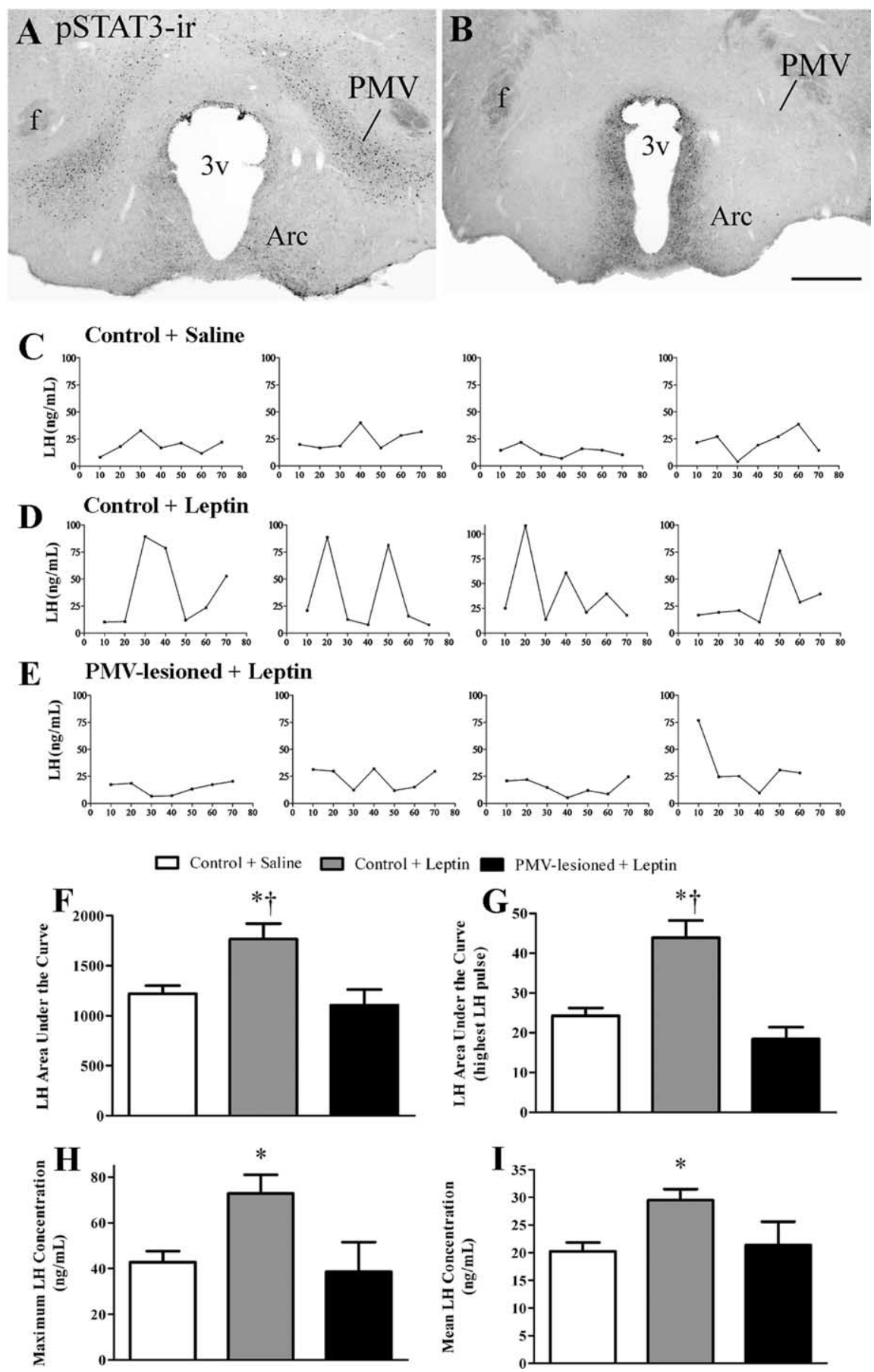

Figure 6. Bilateral lesions of the PMV preclude leptin stimulatory effect on LH secretion in fasted animals. Ovariectomized estrogen-primed rats were fasted for $48 \mathrm{~h}$ and received a single $10 \mu \mathrm{l}$ injection of leptin $(1 \mu \mathrm{g} / \mu \mathrm{l})$ or saline intracerebroventricularly Blood samples were obtained in $10 \mathrm{~min}$ intervals for $70 \mathrm{~min}$, followed by the perfusion. $\boldsymbol{A}, \boldsymbol{B}$, Brightfield photomicrographs showing pSTAT3 immunoreactivity (PSTAT-3-ir) in control $(\boldsymbol{A})$ and PMV-lesioned $(\boldsymbol{B})$ animals after leptin administration. $\boldsymbol{C}-\boldsymbol{E}$, Graphs showing the LH levels across $70 \mathrm{~min}$ after intracerebroventricular injection of saline or leptin in 4 representative cases of control and PMV-lesioned animals. $\boldsymbol{F}-\boldsymbol{I}$, Bar graphs showing $(\boldsymbol{F})$ the LH area under the curve of the entire period analyzed (70 $\min ),(\boldsymbol{G})$ the $L$ H area under the curve of the highest $L H$ pulse, $(\boldsymbol{H})$ the maximum $L H$ concentration, and $(\boldsymbol{I})$ mean $L H$ concentration after leptin administration in nonlesioned $(n=8)$ and in PMV-lesioned $(n=5)$, compared with control animals treated with saline $(n=8)$. *Statistically different $(p<0.05)$ compared with control animals treated with saline, ${ }^{\dagger}$ statistically different $(p<$ 0.05) compared with PMV-lesioned animals treated with leptin. Scale bar, $400 \mu \mathrm{m}$. 3v, Third ventricle; f, fornix.

\section{The PMV role in energy homeostasis}

Leptin's action in regulating energy balance is well established (Elmquist et al., 2005; Schwartz and Porte, 2005). Interestingly, the absence of leptin signaling in PMV neurons caused no 


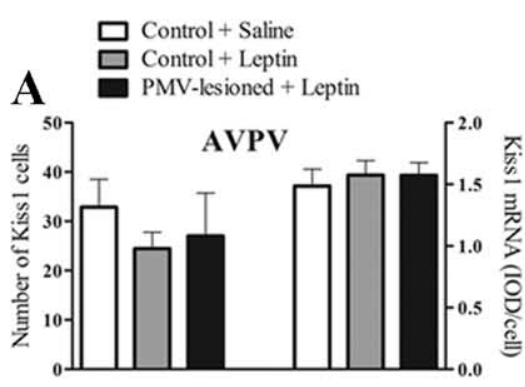

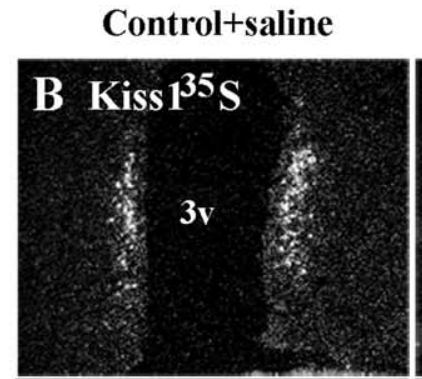
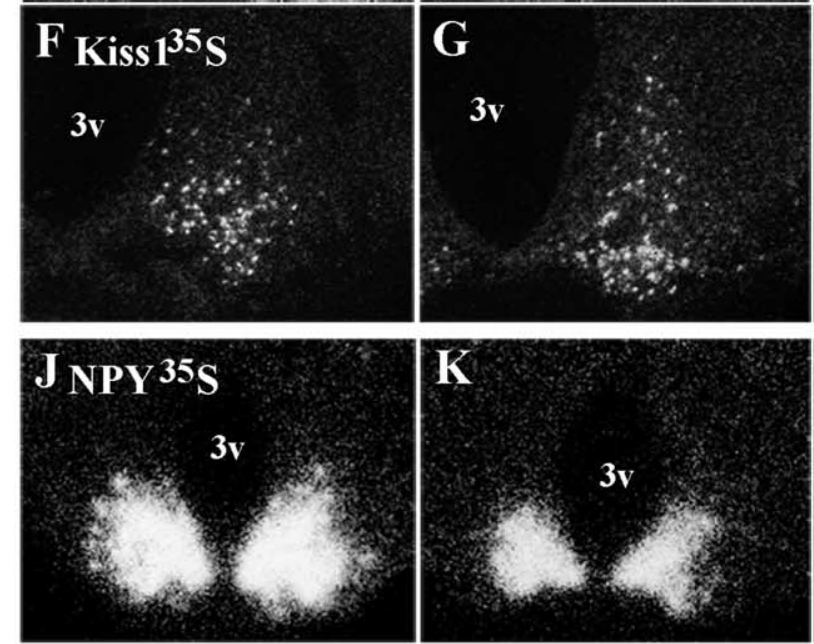

Control+leptin

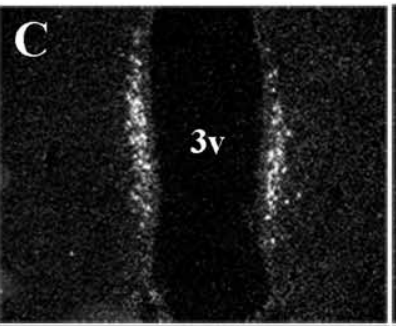

PMV-lesioned+leptin
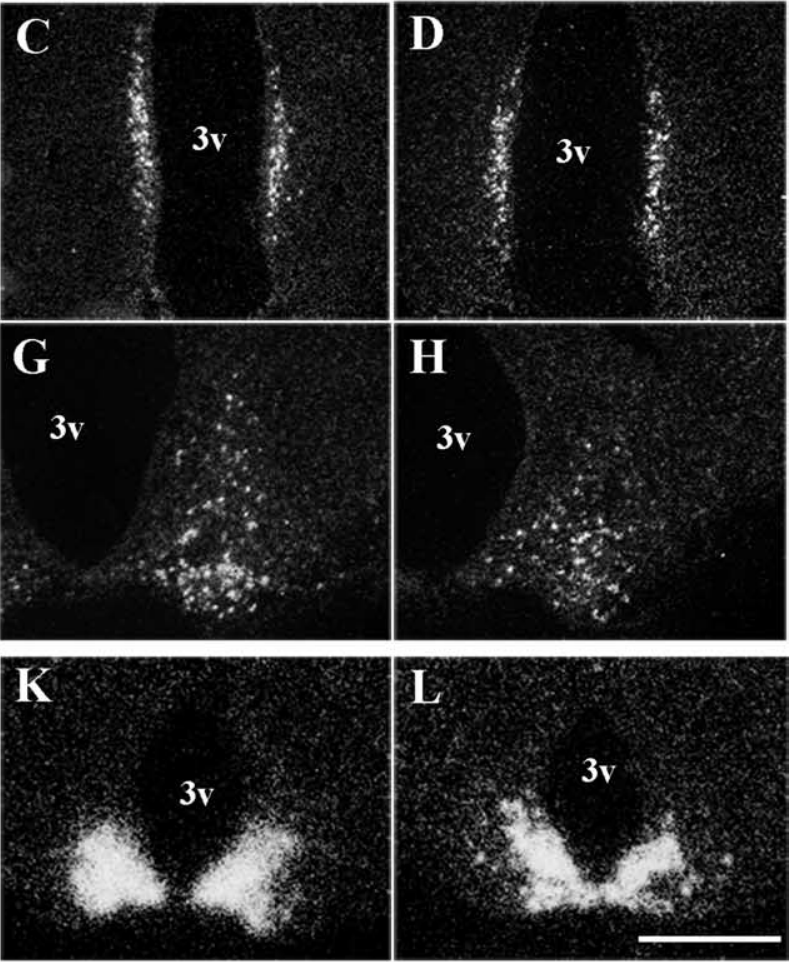

Figure 7. Kiss1 expression and NPY responsiveness to leptin are not affected by lesions of the PMV. $\boldsymbol{A}, \boldsymbol{E}$, Bar graphs showing the number of Kiss 1 cells and the quantification of hybridization signal (IOD/cell) of Kiss1-positive cells in the AVPV $(\boldsymbol{A})$ and in the $\operatorname{Arc}(\boldsymbol{E})$ of nonlesioned saline-treated $(n=8)$, nonlesioned leptin-treated $(n=8)$, and PMV-lesioned leptin-treated ( $n=5)$ animals. No differences were observed for the number of Kiss1 cells (AVPV, $p=0.5105 ;$ Arc, $p=0.3597$ ) and for I0D/cell (AVPV, $p=0.8496 ;$ Arc, $p=0.7195)$ comparing all groups. $\boldsymbol{B}-\boldsymbol{D}, \boldsymbol{F}-\boldsymbol{H}, \mathbf{D a r k f i e l d}$ photomicrographs showing Kiss1 mRNA (silver grains) in the AVPV $(\boldsymbol{B}-\boldsymbol{D})$ and in the Arc $(\boldsymbol{F}-\boldsymbol{H})$ of nonlesioned saline-treated, nonlesioned leptin-treated, and PMV-lesioned leptin-treated animals. $I$, Bar graphs showing the quantification of hybridization signal (IOD of a constant area) of NPY-positive cells in the Arc. The NPY responsiveness to leptin is intact in PMV-lesioned animals as acute intracerebroventricular leptin administration decreased NPY expression in the groups treated with leptin compared with that treated with saline $(p=0.0013$ ). $J-L$, Darkfield photomicrographs showing NPY mRNA in the Arc of nonlesioned saline-treated, nonlesioned leptin-treated, and PMV-lesioned leptin-treated animals. * Statistically different from nonlesioned saline-treated animals. Scale bar: (in $\boldsymbol{L}) \boldsymbol{B}-\boldsymbol{D}, \boldsymbol{F}-\boldsymbol{H}=400 \mu \mathrm{m} ; \boldsymbol{J}-\boldsymbol{L}, 600 \mu \mathrm{m}$. 3v, Third ventricle.

changes in body weight and mean food intake. Prolonged follow-up and different nutritional challenges (as in diet-induced obesity) need to be tested, but our findings suggest that the PMV does not mediate leptin's effects in energy homeostasis. However, we observed that the typical decrease in food intake that takes place in the transition from proestrus to estrus (Asarian and Geary, 2006) was altered in PMV-lesioned animals. The characteristic pattern of food intake across the estrous cycle is thought to be the consequence of fluctuations on estradiol levels (Drewett, 1973; Blaustein and Wade, 1976). Ovariectomy blunts the cyclic variation in food intake, and estrogen administration restores the feeding pattern (Asarian and Geary, 2002). Thus, the decrease in food intake during the night of the behavioral estrus is thought to be the direct consequence of the preceding rise on estrogen levels (Geary et al., 2001; Asarian and Geary, 2006). We propose that the PMV is not directly regulating feeding pattern across estrous cycle, but the decreased levels of estrogen during the proestrus day may be the cause for the results obtained for food consumption.

\section{The PMV is required for leptin's stimulatory effects on LH secretion}

As described by various groups using different experimental designs, leptin administration in conditions of negative energy balance restores LH secretion (Ahima et al., 1996; Nagatani et al., 1998; Gonzalez et al., 1999; Watanobe et al., 1999; Chan et al., 2003; Welt et al., 2004). For example, acute intracerebroventricular leptin administration in fasted male rats increased the LH pulse frequency and amplitude, resulting in increased LH levels (Gonzalez et al., 1999). In agreement, $3 \mathrm{~d}$ fasting abolished the LH surge in ovariectomized estrogen-/ progesterone-primed rats, and continuous subcutaneous infusion of leptin recovered the fasting-induced LH suppression. Notably, leptin did not change the LH surge magnitude when administrated in normally fed animals (Watanobe et al., 1999). As discussed above, lesions of the PMV affected the reproductive physiological responses on periods of high estrogen milieu (afternoon of proestrus). Thus, we assessed the leptin action on LH secretion in ovariectomized animals treated with higher doses of estrogen. We initially assessed, under fasting state and high estrogen levels, whether leptin affects LH levels in nonlesioned animals. In these animals, we observed that intracerebroventricular leptin increased all $\mathrm{LH}$ parameters assessed (AUC, AUC of the highest pulse, maximum level, and mean concentration) compared with saline treated rats. Our findings suggest that, during fasting, intracerebroventricular leptin also induces LH secretion in states of high estrogen levels. However, in the absence of PMV neurons, leptin failed to induce $\mathrm{LH}$ secretion. In all parameters assessed, the PMV-lesioned leptin treated rats were not different from the saline injected animals.

Because the PMV is reciprocally connected with the Arc 
(Canteras et al., 1992), we assessed whether PMV lesions affected Arc neurons (NPY and Kiss1) that have been associated to leptin signaling and reproductive control (Gruaz et al., 1993; Smith et al., 2006a; Hill et al., 2008). The inhibition of NPY neurons is thought to be one of the mechanisms by which leptin modulates the reproductive axis. Animal models or physiologic states characterized by high NPY levels are usually associated to suppression of the reproductive system (Gruaz et al., 1993; Stephens et al., 1995; Ahima et al., 1999; Chehab, 2000; Hill et al., 2008). Here we show that acute intracerebroventricularly leptin administration reduced NPY mRNA expression in all groups of fasted animals, including those with complete lesions of the PMV. These results indicate that the responsiveness of NPY neurons to leptin was intact in PMVlesioned animals.

Studies performed in male $o b / o b$ mice demonstrated that leptin administration increases Kiss 1 expression in the Arc but cause no changes in total hypothalamic Kiss1 content (Smith et al., 2006a; Luque et al., 2007). Kiss1 is also decreased in the hypothalamus of diabetic male rats. Administration of leptin restored hypothalamic Kiss1 expression as well as circulating levels of $\mathrm{LH}$ (Castellano et al., 2006). Thus, these studies suggest that leptin treatment stimulates Kiss 1 neurons in leptin-deficient male mice or diabetic male rats. Interestingly, after $48 \mathrm{~h}$ of fasting, a condition of low leptin levels, ovariectomized and ovariectomized estrogen-primed rats displayed no changes in Kiss1 expression in the Arc (Kalamatianos et al., 2008). We also found no variation of Kiss 1 in ovariectomized estrogen-primed fasted rats treated with leptin compared with those treated with saline. Thus, our results show that, in female rats, the increase in LH secretion in response to leptin administration is independent of changes in Kiss 1 mRNA.

In conclusion, our findings reveal a previously unrecognized role for the PMV in the coordinated control of the neuroendocrine events that occur during the preovulatory LH surge and for leptin's stimulatory effect on LH secretion during fasting. In agreement with others suggesting a dissociation between the brain pathways or signaling cascades mediating multiple leptin actions (Hohmann et al., 2000; Bates et al., 2003), our findings also indicate a segregation between the hypothalamic nuclei recruited by leptin to control reproduction and energy homeostasis.

\section{References}

Ahima RS, Prabakaran D, Mantzoros C, Qu D, Lowell B, Maratos-Flier E, Flier JS (1996) Role of leptin in the neuroendocrine response to fasting. Nature 382:250-252.

Ahima RS, Kelly J, Elmquist JK, Flier JS (1999) Distinct physiologic and neuronal responses to decreased leptin and mild hyperleptinemia. Endocrinology 140:4923-4931.

Anselmo-Franci JA, Franci CR, Krulich L, Antunes-Rodrigues J, McCann SM (1997) Locus coeruleus lesions decrease norepinephrine input into the medial preoptic area and medial basal hypothalamus and block the $\mathrm{LH}$, FSH and prolactin preovulatory surge. Brain Res 767:289-296.

Asarian L, Geary N (2002) Cyclic estradiol treatment normalizes body weight and restores physiological patterns of spontaneous feeding and sexual receptivity in ovariectomized rats. Horm Behav 42:461-471.

Asarian L, Geary N (2006) Modulation of appetite by gonadal steroid hormones. Philos Trans R Soc Lond B Biol Sci 361:1251-1263.

Balthasar N, Coppari R, McMinn J, Liu SM, Lee CE, Tang V, Kenny CD, McGovern RA, Chua SC Jr, Elmquist JK, Lowell BB (2004) Leptin receptor signaling in POMC neurons is required for normal body weight homeostasis. Neuron 42:983-991.

Barash IA, Cheung CC, Weigle DS, Ren H, Kabigting EB, Kuijper JL, Clifton DK, Steiner RA (1996) Leptin is a metabolic signal to the reproductive system. Endocrinology 137:3144-3147.
Bates SH, Stearns WH, Dundon TA, Schubert M, Tso AW, Wang Y, Banks AS, Lavery HJ, Haq AK, Maratos-Flier E, Neel BG, Schwartz MW, Myers MG Jr (2003) STAT3 signalling is required for leptin regulation of energy balance but not reproduction. Nature 421:856-859.

Beltramino C, Taleisnik S (1983) Release of LH in the female rat by olfactory stimuli. Effect of the removal of the vomeronasal organs or lesioning of the accessory olfactory bulbs. Neuroendocrinology 36:53-58.

Beltramino C, Taleisnik S (1985) Ventral premammillary nuclei mediate pheromonal-induced LH release stimuli in the rat. Neuroendocrinology 41:119-124.

Blaustein JD, Wade GN (1976) Ovarian influences on the meal patterns of female rats. Physiol Behav 17:201-208.

Boehm U, Zou Z, Buck LB (2005) Feedback loops link odor and pheromone signaling with reproduction. Cell 123:683-695.

Bond CT, Hayflick JS, Seeburg PH, Adelman JP (1989) The rat gonadotropin-releasing hormone: SH locus: structure and hypothalamic expression. Mol Endocrinol 3:1257-1262.

Bronson FH (1998) Energy balance and ovulation: small cages versus natural habitats. Reprod Fertil Dev 10:127-137.

Canteras NS, Simerly RB, Swanson LW (1992) Projections of the ventral premammillary nucleus. J Comp Neurol 324:195-212.

Castellano JM, Navarro VM, Fernández-Fernández R, Roa J, Vigo E, Pineda R, Dieguez C, Aguilar E, Pinilla L, Tena-Sempere M (2006) Expression of hypothalamic KiSS-1 system and rescue of defective gonadotropic responses by kisspeptin in streptozotocin-induced diabetic male rats. Diabetes 55:2602-2610.

Cavalcante JC, Bittencourt JC, Elias CF (2006) Female odors stimulate CART neurons in the ventral premammillary nucleus of male rats. Physiol Behav 88:160-166.

Chan JL, Heist K, DePaoli AM, Veldhuis JD, Mantzoros CS (2003) The role of falling leptin levels in the neuroendocrine and metabolic adaptation to short-term starvation in healthy men. J Clin Invest 111:1409-1421.

Chan YY, Steiner RA, Clifton DK (1996) Regulation of hypothalamic neuropeptide-Y neurons by growth hormone in the rat. Endocrinology 137:1319-1325.

Chehab FF (2000) Leptin as a regulator of adipose mass and reproduction. Trends Pharmacol Sci 21:309-314.

Chehab FF, Lim ME, Lu R (1996) Correction of the sterility defect in homozygous obese female mice by treatment with the human recombinant leptin. Nat Genet 12:318-320.

Clément K, Vaisse C, Lahlou N, Cabrol S, Pelloux V, Cassuto D, Gourmelen $\mathrm{M}$, Dina $\mathrm{C}$, Chambaz J, Lacorte JM, Basdevant $\mathrm{A}$, Bougnères $\mathrm{P}$, Lebouc $\mathrm{Y}$, Froguel P, Guy-Grand B (1998) A mutation in the human leptin receptor gene causes obesity and pituitary dysfunction. Nature 392:398-401.

Coppari R, Ichinose M, Lee CE, Pullen AE, Kenny CD, McGovern RA, Tang V, Liu SM, Ludwig T, Chua SC Jr, Lowell BB, Elmquist JK (2005) The hypothalamic arcuate nucleus: a key site for mediating leptin's effects on glucose homeostasis and locomotor activity. Cell Metab 1:63-72.

de Luca C, Kowalski TJ, Zhang Y, Elmquist JK, Lee C, Kilimann MW, Ludwig T, Liu SM, Chua SC Jr (2005) Complete rescue of obesity, diabetes, and infertility in $\mathrm{db} / \mathrm{db}$ mice by neuron-specific LEPR-B transgenes. J Clin Invest 115:3484-3493.

de Roux N, Genin E, Carel JC, Matsuda F, Chaussain JL, Milgrom E (2003) Hypogonadotropic hypogonadism due to loss of function of the KiSS1derived peptide receptor GPR54. Proc Natl Acad Sci USA 100:10972-10976.

Drewett RF (1973) Oestrous and dioestrous components of the ovarian inhibition on hunger in the rat. Anim Behav 21:772-780.

Elias CF, Kelly JF, Lee CE, Ahima RS, Drucker DJ, Saper CB, Elmquist JK (2000) Chemical characterization of leptin-activated neurons in the rat brain. J Comp Neurol 423:261-281.

Elmquist JK, Coppari R, Balthasar N, Ichinose M, Lowell BB (2005) Identifying hypothalamic pathways controlling food intake, body weight, and glucose homeostasis. J Comp Neurol 493:63-71.

Erickson JC, Hollopeter G, Palmiter RD (1996) Attenuation of the obesity syndrome of ob/ob mice by the loss of neuropeptide Y. Science 274:1704-1707.

Eskay RL, Mical RS, Porter JC (1977) Relationship between luteinizing hormone releasing hormone concentration in hypophysial portal blood and luteinizing hormone release in intact, castrated, and electrochemicallystimulated rats. Endocrinology 100:263-270.

Farooqi IS, Jebb SA, Langmack G, Lawrence E, Cheetham CH, Prentice AM, 
Hughes IA, McCamish MA, O'Rahilly S (1999) Effects of recombinant leptin therapy in a child with congenital leptin deficiency. N Engl J Med 341:879-884.

Farooqi IS, Matarese G, Lord GM, Keogh JM, Lawrence E, Agwu C, Sanna V, Jebb SA, Perna F, Fontana S, Lechler RI, DePaoli AM, O’Rahilly S (2002) Beneficial effects of leptin on obesity, $\mathrm{T}$ cell hyporesponsiveness, and neuroendocrine/metabolic dysfunction of human congenital leptin deficiency. J Clin Invest 110:1093-1103.

Foster DL, Ebling FJ, Micka AF, Vannerson LA, Bucholtz DC, Wood RI, Suttie JM, Fenner DE (1989) Metabolic interfaces between growth and reproduction. I. Nutritional modulation of gonadotropin, prolactin, and growth hormone secretion in the growth-limited female lamb. Endocrinology 125:342-350.

Geary N, Asarian L, Korach KS, Pfaff DW, Ogawa S (2001) Deficits in E2dependent control of feeding, weight gain, and cholecystokinin satiation in ER-alpha null mice. Endocrinology 142:4751-4757.

Gonzalez LC, Pinilla L, Tena-Sempere M, Aguilar E (1999) Leptin(116130) stimulates prolactin and luteinizing hormone secretion in fasted adult male rats. Neuroendocrinology 70:213-220.

Gruaz NM, Pierroz DD, Rohner-Jeanrenaud F, Sizonenko PC, Aubert ML (1993) Evidence that neuropeptide Y could represent a neuroendocrine inhibitor of sexual maturation in unfavorable metabolic conditions in the rat. Endocrinology 133:1891-1894.

Gu GB, Simerly RB (1997) Projections of the sexually dimorphic anteroventral periventricular nucleus in the female rat. J Comp Neurol 384:142-164.

Hahn JD, Coen CW (2006) Comparative study of the sources of neuronal projections to the site of gonadotrophin-releasing hormone perikarya and to the anteroventral periventricular nucleus in female rats. J Comp Neurol 494:190-214.

Herbison AE (2008) Estrogen positive feedback to gonadotropin-releasing hormone $(\mathrm{GnRH})$ neurons in the rodent: the case for the rostral periventricular area of the third ventricle (RP3V). Brain Res Rev 57:277-287.

Herbison AE, Porteous R, Pape JR, Mora JM, Hurst PR (2008) Gonadotropin-releasing hormone neuron requirements for puberty, ovulation, and fertility. Endocrinology 149:597-604.

Hill JW, Elmquist JK, Elias CF (2008) Hypothalamic pathways linking energy balance and reproduction. Am J Physiol Endocrinol Metab 294:E827-832.

Hoffman GE, Lyo D (2002) Anatomical markers of activity in neuroendocrine systems: are we all 'fos-ed out'? J Neuroendocrinol 14:259-268.

Hohmann JG, Teal TH, Clifton DK, Davis J, Hruby VJ, Han G, Steiner RA (2000) Differential role of melanocortins in mediating leptin's central effects on feeding and reproduction. Am J Physiol Regul Integr Comp Physiol 278:R50-R59.

Jennes L, Stumpf WE (1986) Gonadotropin-releasing hormone immunoreactive neurons with access to fenestrated capillaries in mouse brain. Neuroscience 18:403-416.

Kalamatianos T, Grimshaw SE, Poorun R, Hahn JD, Coen CW (2008) Fasting reduces KiSS-1 expression in the anteroventral periventricular nucleus (AVPV): effects of fasting on the expression of KiSS-1 and neuropeptide $\mathrm{Y}$ in the AVPV or arcuate nucleus of female rats. J Neuroendocrinol 20:1089-1097.

Kinoshita M, Tsukamura H, Adachi S, Matsui H, Uenoyama Y, Iwata K, Yamada S, Inoue K, Ohtaki T, Matsumoto H, Maeda K (2005) Involvement of central metastin in the regulation of preovulatory luteinizing hormone surge and estrous cyclicity in female rats. Endocrinology 146:4431-4436

Le WW, Berghorn KA, Rassnick S, Hoffman GE (1999) Periventricular preoptic area neurons coactivated with luteinizing hormone ( $\mathrm{LH})$-releasing hormone (LHRH) neurons at the time of the LH surge are LHRH afferents. Endocrinology 140:510-519.

Lee WS, Smith MS, Hoffman GE (1990) Luteinizing hormone-releasing hormone neurons express Fos protein during the proestrous surge of luteinizing hormone. Proc Natl Acad Sci U S A 87:5163-5167.

Luque RM, Kineman RD, Tena-Sempere M (2007) Regulation of hypothalamic expression of KiSS-1 and GPR54 genes by metabolic factors: analyses using mouse models and a cell line. Endocrinology 148:4601-4611.

Maffei M, Halaas J, Ravussin E, Pratley RE, Lee GH, Zhang Y, Fei H, Kim S, Lallone R, Ranganathan S, et al (1995) Leptin levels in human and rodent: measurement of plasma leptin and ob RNA in obese and weightreduced subjects. Nat Med 1:1155-1161.
Manning JM, Bronson FH (1989) Effects of prolonged exercise on puberty and luteinizing hormone secretion in female rats. Am J Physiol 257:R1359-R1364.

Montague CT, Farooqi IS, Whitehead JP, Soos MA, Rau H, Wareham NJ, Sewter CP, Digby JE, Mohammed SN, Hurst JA, Cheetham CH, Earley AR, Barnett AH, Prins JB, O'Rahilly S (1997) Congenital leptin deficiency is associated with severe early-onset obesity in humans. Nature 387:903-908.

Nagatani S, Guthikonda P, Thompson RC, Tsukamura H, Maeda KI, Foster DL (1998) Evidence for GnRH regulation by leptin: leptin administration prevents reduced pulsatile LH secretion during fasting. Neuroendocrinology 67:370-376.

Parfitt DB, Church KR, Cameron JL (1991) Restoration of pulsatile luteinizing hormone secretion after fasting in rhesus monkeys (Macaca mulatta): dependence on size of the refeed meal. Endocrinology 129:749-756.

Petersen SL, McCrone S, Keller M, Shores S (1995) Effects of estrogen and progesterone on luteinizing hormone-releasing hormone messenger ribonucleic acid levels: consideration of temporal and neuroanatomical variables. Endocrinology 136:3604-3610.

Roman EA, Ricci AG, Faletti AG (2005) Leptin enhances ovulation and attenuates the effects produced by food restriction. Mol Cell Endocrinol 242:33-41.

Rondini TA, Baddini SP, Sousa LF, Bittencourt JC, Elias CF (2004) Hypothalamic cocaine- and amphetamine-regulated transcript neurons project to areas expressing gonadotropin releasing hormone immunoreactivity and to the anteroventral periventricular nucleus in male and female rats. Neuroscience 125:735-748.

Schwartz MW, Porte D Jr (2005) Diabetes, obesity, and the brain. Science 307:375-379.

Seminara SB, Messager S, Chatzidaki EE, Thresher RR, Acierno JS Jr, Shagoury JK, Bo-Abbas Y, Kuohung W, Schwinof KM, Hendrick AG, Zahn D, Dixon J, Kaiser UB, Slaugenhaupt SA, Gusella JF, O’Rahilly S, Carlton MB, Crowley WF Jr, Aparicio SA, Colledge WH (2003) The GPR54 gene as a regulator of puberty. $\mathrm{N}$ Engl J Med 349:1614-1627.

Silverman AJ, Wilson R, Kesner JS, Knobil E (1986) Hypothalamic localization of multiunit electrical activity associated with pulsatile $\mathrm{LH}$ release in the rhesus monkey. Neuroendocrinology 44:168-171.

Simerly RB, Chang C, Muramatsu M, Swanson LW (1990) Distribution of androgen and estrogen receptor mRNA-containing cells in the rat brain: an in situ hybridization study. J Comp Neurol 294:76-95.

Sisk CL, Nunez AA, Thebert MM (1988) Differential effects of electrolytic and chemical hypothalamic lesions on LH pulses in rats. Am J Physiol 255:E583-590.

Smith JT, Acohido BV, Clifton DK, Steiner RA (2006a) KiSS-1 neurones are direct targets for leptin in the ob/ob mouse. J Neuroendocrinol 18:298-303.

Smith JT, Popa SM, Clifton DK, Hoffman GE, Steiner RA (2006b) Kiss1 neurons in the forebrain as central processors for generating the preovulatory luteinizing hormone surge. J Neurosci 26:6687-6694.

Stephens TW, Basinski M, Bristow PK, Bue-Valleskey JM, Burgett SG, Craft L, Hale J, Hoffmann J, Hsiung HM, Kriauciunas A, et al (1995) The role of neuropeptide $\mathrm{Y}$ in the antiobesity action of the obese gene product. Nature 377:530-532.

Tartaglia LA, Dembski M, Weng X, Deng N, Culpepper J, Devos R, Richards GJ, Campfield LA, Clark FT, Deeds J, Muir C, Sanker S, Moriarty A, Moore KJ, Smutko JS, Mays GG, Wool EA, Monroe CA, Tepper RI (1995) Identification and expression cloning of a leptin receptor, OB-R. Cell 83:1263-1271.

Terry KK, Chatman LA, Foley GL, Kadyszewski E, Fleeman TL, Hurtt ME, Chapin RE (2005) Effects of feed restriction on fertility in female rats. Birth Defects Res B Dev Reprod Toxicol 74:431-441.

van de Wall E, Leshan R, Xu AW, Balthasar N, Coppari R, Liu SM, Jo YH, MacKenzie RG, Allison DB, Dun NJ, Elmquist J, Lowell BB, Barsh GS, de Luca C, Myers MG Jr, Schwartz GJ, Chua SC Jr (2008) Collective and individual functions of leptin receptor modulated neurons controlling metabolism and ingestion. Endocrinology 149:1773-1785.

Wang HJ, Hoffman GE, Smith MS (1995) Increased GnRH mRNA in the GnRH neurons expressing cFos during the proestrous LH surge. Endocrinology 136:3673-3676.

Watanobe H, Suda T, Wikberg JE, Schiöth HB (1999) Evidence that physiological levels of circulating leptin exert a stimulatory effect on luteinizing 
hormone and prolactin surges in rats. Biochem Biophys Res Commun 263:162-165.

Weigle DS, Duell PB, Connor WE, Steiner RA, Soules MR, Kuijper JL (1997) Effect of fasting, refeeding, and dietary fat restriction on plasma leptin levels. J Clin Endocrinol Metab 82:561-565.

Welt CK, Chan JL, Bullen J, Murphy R, Smith P, DePaoli AM, Karalis A, Mantzoros CS (2004) Recombinant human leptin in women with hypothalamic amenorrhea. N Engl J Med 351:987-997.

Wiegand SJ, Terasawa E (1982) Discrete lesions reveal functional heterogeneity of suprachiasmatic structures in regulation of gonadotropin secretion in the female rat. Neuroendocrinology 34:395-404.

Winans SS, Powers JB (1977) Olfactory and vomeronasal deafferentation of male hamsters: histological and behavioral analyses. Brain Res 126:325-344.
Wintermantel TM, Campbell RE, Porteous R, Bock D, Gröne HJ, Todman MG, Korach KS, Greiner E, Pérez CA, Schütz G, Herbison AE (2006) Definition of estrogen receptor pathway critical for estrogen positive feedback to gonadotropin-releasing hormone neurons and fertility. Neuron 52:271-280.

Yeo GS, Farooqi IS, Aminian S, Halsall DJ, Stanhope RG, O’Rahilly S (1998) A frameshift mutation in MC4R associated with dominantly inherited human obesity. Nat Genet 20:111-112.

Zamorano PL, Mahesh VB, De Sevilla LM, Chorich LP, Bhat GK, Brann DW (1997) Expression and localization of the leptin receptor in endocrine and neuroendocrine tissues of the rat. Neuroendocrinology 65:223-228.

Zhang Y, Proenca R, Maffei M, Barone M, Leopold L, Friedman JM (1994) Positional cloning of the mouse obese gene and its human homologue. Nature 372:425-432. 